\title{
Evidence of Low-Habitat Contamination Using Feathers of Three Heron Species as a Biomonitor of Inorganic Elemental Pollution
}

\author{
Luca Canova *, Michela Sturini ${ }^{\mathbb{D}}$, Antonella Profumo ${ }^{\mathbb{D}}$ and Federica Maraschi ${ }^{\mathbb{D}}$ \\ Department of Chemistry, University of Pavia, I-27100 Pavia, Italy; michela.sturini@unipv.it (M.S.); \\ antonella.profumo@unipv.it (A.P.); federica.maraschi@unipv.it (F.M.) \\ * Correspondence: canova@unipv.it
}

Received: 24 September 2020; Accepted: 21 October 2020; Published: 23 October 2020

\begin{abstract}
The concentration of 12 elements (As, Cd, Co, Cr, Cu, Fe, Hg, Mn, Ni, Pb, Se, and Zn) has been investigated in the feathers of three species of Ardeidae, namely the Grey Heron Ardea cinerea, the Little Egret Egretta garzetta, and the Cattle Egret Bubulcus ibis, all breeding at a colony located in the southern Padana Plain (NW Italy). This study is a first step for an evaluation of possible direct effects of these elements on chicks' survival and growth rate. $\mathrm{Fe}, \mathrm{Zn}, \mathrm{Cu}$, and $\mathrm{Mn}$ were in the range 7-69 $\mathrm{mg} \mathrm{Kg}^{-1}$, while lower levels of $\mathrm{Pb}, \mathrm{Ni}$, As, and Se (0.27-1.45 $\mathrm{mg} \mathrm{Kg}^{-1}$ ) were measured. $\mathrm{Co}, \mathrm{Cd}$, and $\mathrm{Cr}$ were close to the method detection limits (MDLs) in all the species. The measured concentrations of the most abundant trace elements, such as $\mathrm{Zn}$ and $\mathrm{Cu}$, seem to reflect the geochemical pattern of the background (running water and soil), while $\mathrm{Hg}$ concentration is lower and it appears to be biomagnified, particularly in Grey Heron feathers. Its concentration is higher in adults than in chicks, and it differs among the three species, as it is closely related to the fish-based dietary pattern. The measured trace elements' concentrations are below the threshold levels in all the heron species, and consequently, harmful and acute effects on the local population are unlikely; the conservation status of herons populations in northern Italy is probably more affected by other factors, such as climate changes, altered aquatic environment, and, consequently, food quality.
\end{abstract}

Keywords: Grey Heron Ardea cinerea; Little Egret Egretta garzetta; Cattle Egret Bubulcus ibis; biomonitoring of inorganic elements; trophic ecology

\section{Introduction}

Inorganic elemental pollutants enters the environment due to anthropogenic activities, such as industry, agriculture, and natural processes. They are present in rivers, lagoons, and marshes, which are currently the most threatened aquatic ecosystems in the world [1,2]; some elements persist in the environment for extended periods and, due to their high bioavailability in water [3], they can concentrate through the food chain and negatively affect birds foraging in the aquatic habitats $[4,5]$.

Biological organisms, at different trophic levels, are often used as bioindicators to provide evidence of the potential adverse effects of exposure to contaminants [6,7]. Monitoring of metals in bird species is useful to assess their health and, at the same time, to evaluate the degree of contamination of the ecosystems where they live [8,9].

Exposure to high levels of metals is associated with various neurological, physiological, reproductive, developmental, and behavioral disorders of birds [10,11]. Moreover, it is responsible for oxidative damage, as detoxification and excretion are expensive metabolic processes leading to oxidative stress [12,13]. High concentrations of heavy elements can result in eggshell thinning, reproductive failure and immunosuppression, adverse developmental effects, as well as embryo 
malformations and mortality, which are all factors contributing to population decline. For instance, exposure to cadmium $(\mathrm{Cd})$, mercury $(\mathrm{Hg})$, and selenium (Se) negatively affects the body mass/condition and health of birds by reducing their growth or body weight and, consequently, it harms survival and reproductive success [14,15]. Hg accumulated in body tissues can adversely affect reproduction, especially in higher trophic level species, such as fish-eating birds [16-18].

Colonial herons are species of special concern in Europe; their conservation status has been considerably improved in the last 30 years and many heronries are currently protected. However, several species are threatened by factors that overrule local and European authorities, such as drought and habitat destruction in African wintering quartiers for migrating species, change in water and food availability and quality in Southern Europe, as well as pollution and reduction of suitable breeding sites in Italy. Water pollution can be an important threat both for adults and chicks, since nearly all the species feed on aquatic prey and can bioaccumulate and biomagnify harmful pollutants.

Herons can be good indicators of elemental exposure for different reasons including the following: (i) they feed in the aquatic habitat; (ii) they are long-lived organisms; (iii) they are secondary consumers, and thus exposed to a wide range of chemicals; and (iv) their position at the top of the food chain makes them susceptible to bioaccumulation of heavy metals from various sources [19-21]. Many tissues of birds, such as feathers, liver, bones, and blood, but also eggs and eggshells, have been used to monitor avian exposure and assess the risk [22-25]. Among these, feathers have many advantages because they can be obtained quickly and repeatedly from the same individual without affecting its health, and their preservation does not require refrigeration [25]. Moreover, in the case of herons, feathers reflect the local contamination better than other tissues, because chicks feed on prey collected close to the colony, and considerable amounts of elements are stored in the feathers during the breeding of chicks [26].

In this work, we analyzed twelve elements, arsenic (As), cadmium (Cd), cobalt (Co), chromium $(\mathrm{Cr})$, copper $(\mathrm{Cu})$, iron $(\mathrm{Fe})$, mercury $(\mathrm{Hg})$, manganese $(\mathrm{Mn})$, nickel $(\mathrm{Ni})$, lead $(\mathrm{Pb})$, selenium $(\mathrm{Se})$ and zinc $(\mathrm{Zn})$ in feathers of three heron species breeding in NW Italy. The main objectives of the research were to (i) estimate concentrations levels of trace elements in feathers of both adults and chicks, (ii) detect a possible risk for the conservation status in three heron species (Grey Heron Ardea cinerea, Little Egret Egretta garzetta, and Cattle Egret Bubulcus ibis), (iii) identify a possible relation among elements' concentrations and diet of the examined species, and (iv) provide useful data for future comparisons and observations.

\section{Materials and Methods}

\subsection{Sample Collection}

We collected feathers of three breeding heron species, Little Egret Egretta garzetta, Grey Heron Ardea cinerea, and Cattle Egret Bubulcus ibis in the Sic IT2090001 "Monticchie" (NW Italy, coordinates $45^{\circ} 08^{\prime} 43.12^{\prime \prime} \mathrm{N}, 9^{\circ} 39^{\prime} 26.34^{\prime \prime} \mathrm{E}$ ) in May 2018 and 2019, corresponding to the late breeding season for these species. Adults' and chicks' feathers, wing or chest, were collected inside nests or from the body and quickly preserved in plastic bags. In order to avoid data redundancy, a single feather was collected from each chick lying in each nest. Sixty-five feathers were collected from both young and adult herons as follows: A. cinerea (12 adults and 5 chicks), E. garzetta (15 adults and 8 chicks), and B. ibis (17 adults and 8 chicks).

\subsection{Laboratory Analyses}

Ultrapure $\mathrm{HNO}_{3}$, Trace-SELECT ${ }^{\circledR}(65 \% \mathrm{w} / \mathrm{w}), \mathrm{H}_{2} \mathrm{O}_{2}(30 \% \mathrm{w} / \mathrm{w})$, and certified multi-standard solution Merck VI for ICP-MS were purchased from Sigma-Aldrich (Milan, Italy). The multi-element standard solutions were prepared daily in $0.5 \%$ ultrapure $\mathrm{HNO}_{3}$. Ultrapure water was produced in the laboratory by a Millipore Milli-Q system.

A CEM Mars microwave oven (CEM s.r.l., Cologno al Serio, Italy) equipped with eight PTFE vessels (Xpress, $55 \mathrm{~mL}$ ) was used for sample digestion. XpressVapTM accessory was employed for 
the evaporation of the digested acid solutions. Measurements were performed using an inductively coupled plasma quadrupole mass spectrometer (ICP-MS) (Elan DRC-e, PerkineElmer, Shelton, CT, USA) equipped with standard ICP torch, cross-flow nebulizer, nickel sampler, skimmer cones, and dynamic reaction cell ${ }^{\mathrm{TM}}(\mathrm{DRC})$.

\subsection{Analytical Procedure}

The feathers were vigorously washed in deionized water, sonicated for $5 \mathrm{~min}$ in in acetone $/ \mathrm{H}_{2} \mathrm{O}$ 1:10) and air-dried before the dissolution step. The whole feather from each individual was processed. Feathers, 20-150 mg, were accurately weighed into the PTFE vessels of the microwave digestion system, and $5 \mathrm{~mL}$ of $\mathrm{HNO}_{3}$ plus $2 \mathrm{~mL}$ of $\mathrm{H}_{2} \mathrm{O}_{2}$ were added. Then microwave heating was performed at $1600 \mathrm{~W}$ for $15 \mathrm{~min}, 200{ }^{\circ} \mathrm{C}$. After cooling, the contents were evaporated to a small volume (about $0.5 \mathrm{~mL}$ ), diluted to $10 \mathrm{~mL}$ with MQ water in calibrated polypropylene tubes, and analyzed by DRC-ICP-MS for metals determination. Three-point calibration curves were generated in the range 5-500 $\mu \mathrm{g} \mathrm{L}^{-1}$. Method detection and quantification limits (MDLs, MQLs) were obtained from the instrumental detection and quantification limits (IDLs, IQLs) calculated using the residual standard deviation (Sy/x) of the linear regression parameters as $(3.3 \times \mathrm{Sy} / \mathrm{x}) /$ slope and $(10 \times \mathrm{Sy} / \mathrm{x}) /$ slope, respectively, referred to in the overall procedure (See Table A1). Reagent blanks were prepared following the same procedure applied to samples. Five sets of method blank and certified reference material (BCR-397, trace elements in human hair) were processed and analyzed concurrently with the samples. The final concentrations were reported as $\mathrm{mg} / \mathrm{Kg}$ dry weight.

\subsection{Statistical Analyses}

Univariate analysis of variance was used to test differences in the concentration levels of elements among species, years, and age, and a post hoc multiple comparison Tukey test was carried out to investigate differences among species when the null hypothesis in one-way ANOVA was rejected. Discriminant function analysis was run on log-transformed values of the significantly different variables, to obtain multivariate discrimination and a classification criterion. The non-parametric Mann-Whitney $\mathrm{U}$ test was adopted to test for differences in $\mathrm{Se} / \mathrm{Hg}$ ratio between species and age classes. All the analyses were performed using the SPSS statistical software (IBM SPSS Statistics Inc. version 13.0).

\section{Results}

Descriptive statistics of the investigated trace elements in the feathers of Grey Heron Ardea cinerea, Little Egret Egretta garzetta, and Cattle Egret Bubulcus ibis are listed in Table 1. Variance analysis was carried out to test the difference in elements' concentrations among species and year.

Concentrations in feathers did not change among years $\left(\mathrm{F}_{1,63}=0.27, p=0.60\right)$, while significant differences occurred among species. In particular, relatively high levels of Zn (from 45 to $69 \mathrm{mg} \mathrm{Kg}^{-1}$ in Cattle Egret and Gray Heron, respectively), Fe (from 57 to $63 \mathrm{mg} \mathrm{Kg}^{-1}$ in Cattle Egret and Gray Heron, respectively), $\mathrm{Cu}$ (from 10.3 to $17 \mathrm{mg} \mathrm{Kg}^{-1}$ in Gray Heron and Cattle Egret, respectively) and $\mathrm{Mn}$ (from 7 to $13 \mathrm{mg} \mathrm{Kg}^{-1}$ in Little Egret and Grey Heron, respectively) were detected. $\mathrm{Fe}, \mathrm{Zn}, \mathrm{Mn}$, and $\mathrm{Cu}$ concentrations decreased following the order $\mathrm{Fe}>\mathrm{Zn}>\mathrm{Cu}>\mathrm{Mn}$ in Little Egret and Cattle Egret, while in Grey Heron the order was $\mathrm{Zn}>\mathrm{Fe}>\mathrm{Mn}>\mathrm{Cu}$. $\mathrm{Hg}$ and Ni levels were significantly higher in Grey Heron (2.8-1.3 $\left.\mathrm{mg} \mathrm{Kg}^{-1}\right)$ than in Little Egret $\left(0.7-0.57 \mathrm{mg} \mathrm{Kg}^{-1}\right)$ and Cattle Egret $\left(0.7-0.50 \mathrm{mg} \mathrm{Kg}^{-1}\right.$, $\left.\mathrm{F}_{2,62}=57.5, p<0.0001\right)$, while the contrary was observed for As $\left(\mathrm{F}_{2,62}=4.47, p=0.015\right)$. There were no significant differences in $\mathrm{Pb}$ and $\mathrm{Cr}$ levels among the species; $\mathrm{Co}$ and $\mathrm{Cd}$ were close to the MDLs for all species, and thus they were discarded from further analyses.

Post hoc comparisons showed differences between the Grey Heron and the Little Egret-Cattle Egret pair (Tukey HSD test, Table 1). Significantly higher concentrations of $\mathrm{Zn}, \mathrm{Hg}$, $\mathrm{Mn}$, and $\mathrm{Ni}$, and lower concentrations of $\mathrm{Cu}$ and As, were detected in Grey Heron and Little Egret, while $\mathrm{Zn}, \mathrm{Hg}$, $\mathrm{Mn}, \mathrm{Cr}, \mathrm{Ni}$, and Se were lower in Cattle Egret than in Grey Heron. There were no significant differences in element concentrations between Little Egret and Cattle Egret (Table 1). 
Table 1. Descriptive statistics (mean \pm SE, minimum-maximum) for trace elements' concentrations in feathers of Grey Heron (Ardea cinerea), Little Egret (Egretta garzetta) and Cattle Egret (Bubulcus ibis). Data are expressed as $\mathrm{mg} \mathrm{Kg}^{-1}$. Tukey post hoc test shows significant differences at $p<0.05\left(^{*}\right), p<0.01(* *)$, and $p<0.001(* * *)$ for ab (A.cinerea-E.garzetta), bc (E.garzetta-B.ibis) and ac (A.cinerea-B.ibis) pairs; ns = not significant. Method quantification limit (MQL) = 0.05 (see Table A1 for MQLs values).

\begin{tabular}{|c|c|c|c|c|c|c|c|c|}
\hline & $\mathbf{a}$ & $\mathbf{b}$ & c & \multicolumn{5}{|c|}{ Tukey Test } \\
\hline & A. cinerea $(\mathrm{n}=17)$ & E. garzetta $(\mathrm{n}=23)$ & B. ibis $(\mathrm{n}=25)$ & $F_{2,62}$ & $p$ & $\mathbf{a b}$ & bc & ac \\
\hline As & $0.27 \pm 0.03(0.12-0.42)$ & $0.6 \pm 0.1(0.1-1.9)$ & $0.5 \pm 0.1(0.1-2.3)$ & 4.47 & 0.015 & $*$ & ns & ns \\
\hline $\mathrm{Cd}^{\bullet}$ & $0.04 \pm 0.02(<\mathrm{MQL}-0.06)$ & $0.05 \pm 0.01(0.05-0.30)$ & $0.06 \pm 0.01(0.05-0.19)$ & 0.28 & 0.281 & ns & ns & ns \\
\hline $\mathrm{Co}$ & $0.09 \pm 0.08(0.02-0.10)$ & $0.07 \pm 0.01(0.02-0.15)$ & $0.07 \pm 0.01(0.02-0.13)$ & 2.78 & 0.069 & $\mathrm{~ns}$ & ns & ns \\
\hline $\mathrm{Cr}$ & $0.59 \pm 0.03(0.43-0.79)$ & $0.48 \pm 0.07(0.08-1.81)$ & $0.40 \pm 0.04(0.15-0.78)$ & 3.04 & 0.051 & ns & ns & $*$ \\
\hline $\mathrm{Cu}$ & $10.3 \pm 0.5(7.1-11.9)$ & $13.3 \pm 0.8(8.3-24.7)$ & $17 \pm 3(5-80)$ & 4.20 & 0.019 & $* *$ & ns & ns \\
\hline $\mathrm{Fe}$ & $63 \pm 9(25-125)$ & $62 \pm 11(6-248)$ & $57 \pm 5(13-142)$ & 0.14 & 0.872 & ns & ns & ns \\
\hline $\mathrm{Hg}$ & $2.8 \pm 0.2(1.5-3.2)$ & $0.7 \pm 0.1(0.2-2.3)$ & $0.7 \pm 0.2(0.2-4.2)$ & 57.48 & $<0.001$ & $* * *$ & ns & $* * *$ \\
\hline $\mathrm{Mn}$ & $13 \pm 1(8-18)$ & $7 \pm 1(1-24)$ & $7.6 \pm 0.9(2.3-23.2)$ & 20.19 & $<0.001$ & $* * *$ & ns & $* *$ \\
\hline $\mathrm{Ni}$ & $1.3 \pm 0.2(0.4-2.8)$ & $0.57 \pm 0.07(0.11-1.58)$ & $0.50 \pm 0.05(0.14-1.15)$ & 12.29 & $<0.001$ & $* * *$ & ns & $* * *$ \\
\hline $\mathrm{Pb}$ & $0.67 \pm 0.04(0.45-0.84)$ & $0.53 \pm 0.06(0.15-1.14)$ & $0.64 \pm 0.08(0.15-1.67)$ & 1.23 & 0.299 & ns & ns & ns \\
\hline Se & $1.45 \pm 0.09(1.00-1.98)$ & $1.22 \pm 0.07(0.73-2.15)$ & $1.18 \pm 0.08(0.57-1.98)$ & 5.71 & 0.005 & $\mathrm{~ns}$ & ns & * \\
\hline $\mathrm{Zn}$ & $69 \pm 32(50-83)$ & $47 \pm 4(6-86)$ & $45 \pm 3(9-64)$ & 15.44 & $<0.001$ & $* * *$ & ns & $* * *$ \\
\hline
\end{tabular}


A discriminant analysis was run on log-transformed concentration values that significantly differed in variance (Table 1). As shown in Figure 1, Grey Heron was well separated from Little Egret and Cattle Egret along a single axis, which accounted for $98.4 \%$ of the total variance (Wilk's lambda $=0.16$, $\left.\chi^{2}=106.5, p<0.001\right) ; \mathrm{Hg}$ and $\mathrm{Zn}$ showed the highest absolute correlation with a discriminant function that predicted $71 \%$ of the total cases correctly.

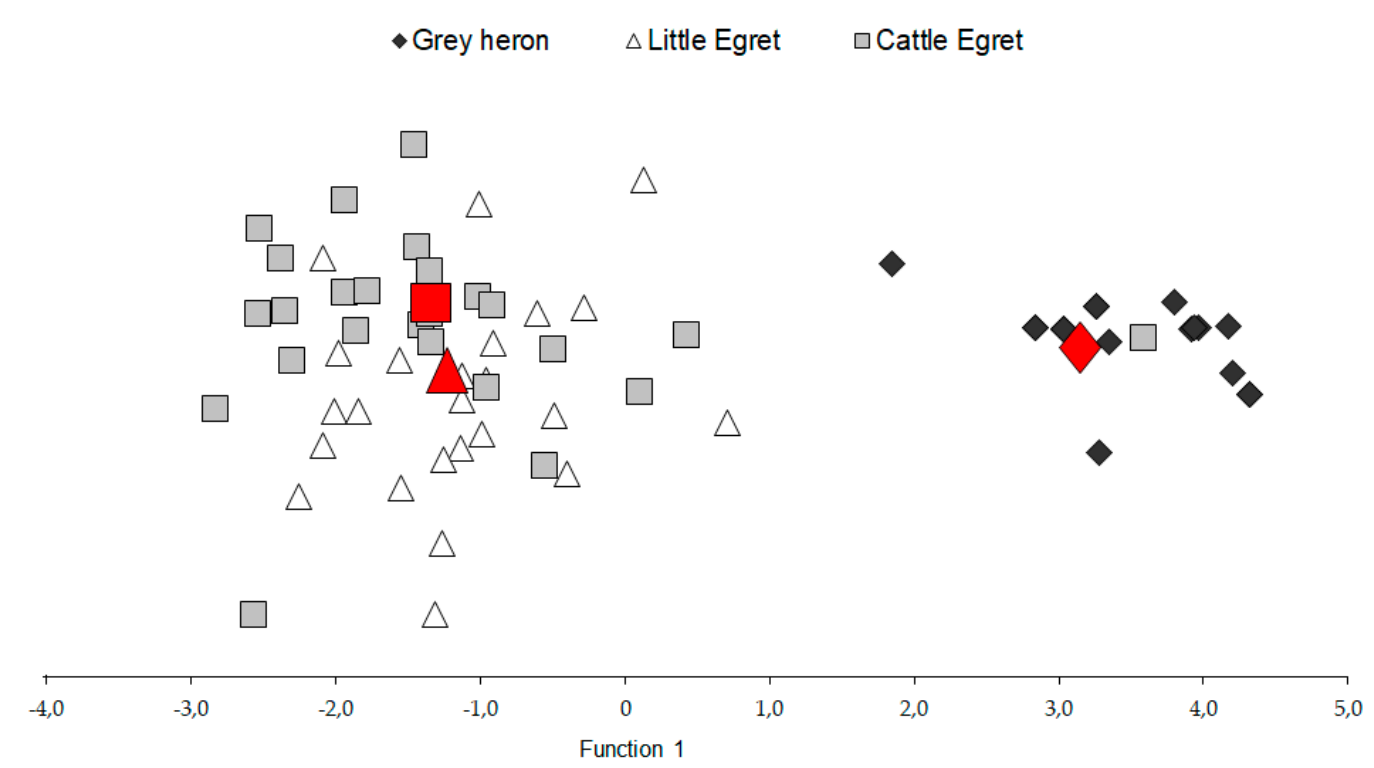

Figure 1. Discriminant analysis and group centroids ( $\bullet$ Grey Heron; $\Delta$ Little Egret; $₫$ Cattle Egret). Red geometric shapes show group centroids. Since function 1 accounts for more than $98 \%$ of total variances, only the distribution on the $\mathrm{x}$-axis is discussed in the text.

Elements' concentrations in adults and juveniles are listed in Table 2. Significant differences were observed for some of them, in particular for two metals in Cattle Egret, five metals in Little Egret, and six metals in the Grey Heron samples. Concentrations were significantly higher in adults than in chicks, as evident for $\mathrm{As}, \mathrm{Cu}, \mathrm{Hg}$, and $\mathrm{Mn}$ but not for Fe and Se in Grey Heron; $\mathrm{Hg}$ but not $\mathrm{Mn}$ in Cattle Egret; and $\mathrm{Cu}, \mathrm{Hg}, \mathrm{Pb}, \mathrm{Cr}$, and $\mathrm{Ni}$ in Little Egret. $\mathrm{Hg}$ concentrations were significantly higher in adults than in chicks for all the species; the lowest differences occurred in Grey Heron and the highest occurred in Cattle Egret (Figure 2). 
Table 2. Differences between trace elements' concentrations in adults and juveniles feathers of Grey Heron (A. cinerea), Little Egret (E. garzetta), and Cattle Egret (B. ibis); $\mathrm{ns}=$ not significant. Mean \pm SE. Data are expressed as $\mathrm{mg} \mathrm{kg}^{-1}$.

\begin{tabular}{|c|c|c|c|c|c|c|c|c|c|c|c|c|}
\hline & \multicolumn{4}{|c|}{ A. cinerea } & \multicolumn{4}{|c|}{ E. garzetta } & \multicolumn{4}{|c|}{ B. ibis } \\
\hline & Ad. $(n=12)$ & Juv. $(n=5)$ & $\mathbf{t}$ & $p$ & Ad. $(n=15)$ & Juv. $(n=8)$ & $\mathbf{t}$ & $p$ & Ad. $(n=17)$ & Juv. $(n=8)$ & $\mathbf{t}$ & $p$ \\
\hline As & $0.31 \pm 0.04$ & $0.19 \pm 0.03$ & 2.51 & 0.021 & $0.7 \pm 0.1$ & $0.4 \pm 0.1$ & 1.25 & ns & $0.5 \pm 0.1$ & $0.6 \pm 0.2$ & -0.27 & $\mathrm{~ns}$ \\
\hline $\mathrm{Cd}$ & $0.04 \pm 0.01$ & $0.04 \pm 0.01$ & 0.02 & ns & $0.06 \pm 0.02$ & $0.04 \pm 0.01$ & 1.02 & ns & $0.06 \pm 0.01$ & $0.06 \pm 0.01$ & 0.03 & ns \\
\hline Co & $0.085 \pm 0.001$ & $0.096 \pm 0.002$ & -4.81 & 0.001 & $0.08 \pm 0.01$ & $0.052 \pm 0.005$ & 2.44 & ns & $0.069 \pm 0.008$ & $0.073 \pm 0.008$ & 0.10 & ns \\
\hline $\mathrm{Cr}$ & $0.61 \pm 0.04$ & $0.53 \pm 0.07$ & 1.03 & ns & $0.6 \pm 0.1$ & $0.31 \pm 0.06$ & 2.30 & 0.032 & $0.39 \pm 0.05$ & $0.42 \pm 0.06$ & -0.36 & ns \\
\hline $\mathrm{Cu}$ & $11.2 \pm 0.2$ & $8.0 \pm 0.9$ & 4.71 & 0.001 & $15 \pm 1$ & $10.5 \pm 0.6$ & 2.80 & 0.011 & $15 \pm 2$ & $22 \pm 8$ & -1.14 & ns \\
\hline $\mathrm{Fe}$ & $45 \pm 9$ & $105 \pm 12$ & -3.81 & 0.002 & $71 \pm 17$ & $45 \pm 9$ & 1.07 & ns & $54 \pm 5$ & $63 \pm 13$ & -0.82 & ns \\
\hline $\mathrm{Hg}$ & $3.20 \pm 0.01$ & $1.8 \pm 0.3$ & 9.19 & 0.001 & $0.9 \pm 0.1$ & $0.32 \pm 0.02$ & 3.22 & 0.004 & $0.9 \pm 0.2$ & $0.21 \pm 0.01$ & 2.97 & 0.009 \\
\hline $\mathrm{Mn}$ & $15 \pm 1$ & $7.64 \pm 0.04$ & 5.16 & 0.001 & $8 \pm 1$ & $4.6 \pm 0.7$ & 1.59 & ns & $6.3 \pm 0.8$ & $10 \pm 2$ & -2.37 & 0.027 \\
\hline $\mathrm{Ni}$ & $1.4 \pm 0.2$ & $0.9 \pm 0.5$ & 0.98 & ns & $0.7 \pm 0.1$ & $0.33 \pm 0.07$ & 2.79 & 0.013 & $0.47 \pm 0.05$ & $0.6 \pm 0.1$ & -1.04 & ns \\
\hline $\mathrm{Pb}$ & $0.70 \pm 0.05$ & $0.61 \pm 0.06$ & 0.94 & ns & $0.62 \pm 0.06$ & $0.38 \pm 0.08$ & 2.26 & 0.035 & $0.7 \pm 0.1$ & $0.54 \pm 0.09$ & 0.85 & ns \\
\hline $\mathrm{Se}$ & $1.32 \pm 0.07$ & $1.8 \pm 0.2$ & 2.83 & 0.013 & $1.15 \pm 0.09$ & $1.4 \pm 0.1$ & 1.45 & ns & $1.2 \pm 0.1$ & $1.08 \pm 0.09$ & 0.87 & ns \\
\hline $\mathrm{Zn}$ & $65 \pm 3$ & $77 \pm 7$ & -1.76 & ns & $45 \pm 6$ & $50 \pm 5$ & 0.56 & ns & $45 \pm 3$ & $46 \pm 5$ & -0.11 & ns \\
\hline
\end{tabular}




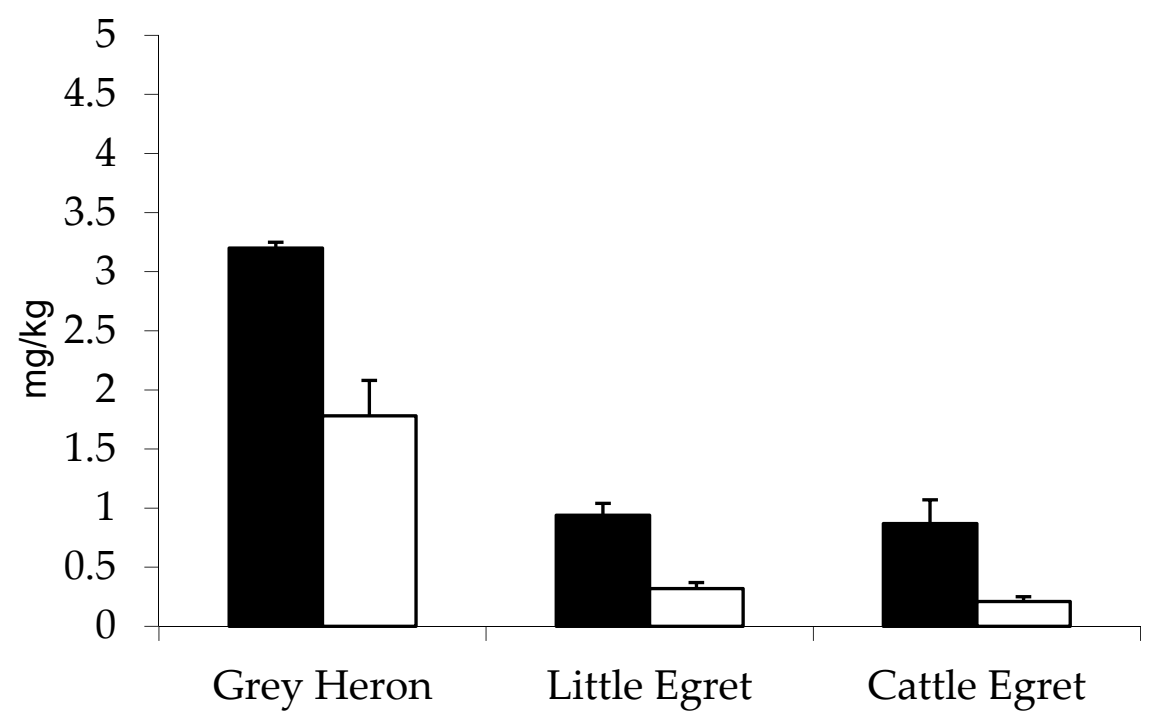

Figure 2. Average concentration and SE of mercury $(\mathrm{Hg})$ in adults' (black) and chicks' (white) feathers.

Data are expressed as $\mathrm{mg} \mathrm{Kg}^{-1} \pm \mathrm{SE}$.

Figure 3 shows an overview of the elements' concentrations, in the logarithmic scale, in the background surrounding the study area (running water, $\mu \mathrm{g} / \mathrm{L}$ and soil, $\mathrm{mg} / \mathrm{kg}$ ) for eight out of the 12 trace elements. $\mathrm{Zn}$ and $\mathrm{Cu}$ are the most abundant elements both in the background and feathers; $\mathrm{Cr}, \mathrm{As}, \mathrm{Pb}$, and $\mathrm{Ni}$ levels are higher in the background than in feathers; $\mathrm{Hg}$ levels are higher in feathers than in background; $\mathrm{Cd}$ is the element with the lowest concentration in all samples.

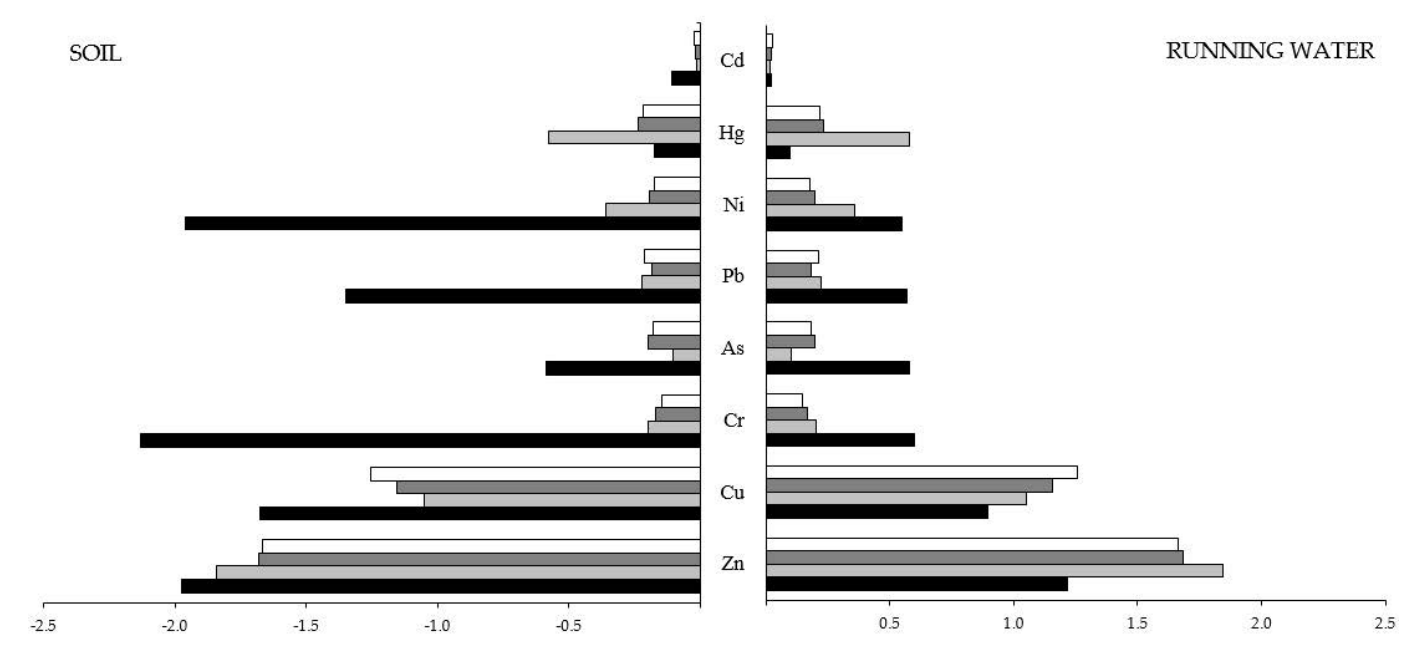

Figure 3. Comparison of the concentrations of the trace elements in the background (soil [27], water [28]) and in the feathers (black, background; pale grey, Grey Heron; dark grey, Little Egret; white, Cattle Egret). Data are $\log _{10}+1$ transformed to emphasize the comparison.

\section{Discussion}

The study of the effects of heavy metals and elements on the ecology of vertebrates is useful to understand their impact on behavior, reproduction, survival $[29,30]$ and, consequently, to improve conservation management for several species [31,32]. Many species of Ardeidae are gregarious, and the distribution of colonies is strongly aggregated; as a consequence, they share relatively restricted foraging areas and may be exposed to potential risks when foraging habitats are polluted [33]. 
The Lambro and Po rivers flow onto the Padana Plain (NW Italy) from North to South and from East to West respectively, the former collecting pollutants mainly from industrial activities and the latter from agriculture [34]; The Lambro river, which has been one of the most polluted rivers of Italy since World War II, flows into the Po river at less than $5 \mathrm{~km}$ from the site where the samples were collected, a radius that overcompasses the average foraging distance of several heron species.

\section{1. $\mathrm{Fe}, \mathrm{Zn}, \mathrm{Cu}$, and $\mathrm{Mn}$}

As expected, the most abundant elements in Grey Herons' feathers are $\mathrm{Cu}, \mathrm{Zn}, \mathrm{Fe}$, and $\mathrm{Mn}$. They are ubiquitous elements, considering their widespread distribution in the terrestrial and aquatic environments of the Mediterranean basin. The $\mathrm{Zn}$ concentrations range from 6 to $86 \mathrm{mg} \mathrm{Kg}^{-1}$ in Little Egret, from 9 to $64 \mathrm{mg} \mathrm{Kg}^{-1}$ in Cattle Egret, and from 50 to $83 \mathrm{mg} \mathrm{Kg}^{-1}$ in Grey Heron (Table 1). A toxicosis threshold limit of $1200 \mathrm{mg} \mathrm{Kg}^{-1}$ was reported by Solgi et al. [35]; therefore, detrimental effects on the population investigated in the present study can certainly be excluded. Copper concentrations vary from a minimum value of $7.1 \mathrm{mg} \mathrm{Kg}^{-1}$ in Grey Heron to a maximum of $80 \mathrm{mg} \mathrm{Kg}^{-1}$ in Cattle Egret, while the average concentration ranges from 10.3 in Grey Heron to $17 \mathrm{mg} \mathrm{Kg}^{-1}$ in Cattle Egret.

The high concentrations of $\mathrm{Cu}$ and $\mathrm{Zn}$, also present in the background, may be due to the extensive use of fungicides and bactericides in agriculture and to the presence of residue from electro-galvanic industrial activities in Northern Italy, especially in the metropolitan areas around the Lambro river [34]. Similar results (range $43-53 \mathrm{mg} \mathrm{Kg}^{-1}$ ) were reported by Rubio et al. [36] for Little Egret in the Odiel delta and by Eisler [37] in body tissues of birds feeding in polluted areas. In general, $\mathrm{Mn}, \mathrm{Zn}, \mathrm{Fe}$, and $\mathrm{Cu}$ patterns are similar to those reported in the literature for the same species from different habitats, suggesting that these concentration levels represent both background and ecological levels $[36,38]$.

\section{2. $\mathrm{As}, \mathrm{Pb}, \mathrm{Cr}, \mathrm{Ni}, \mathrm{Cd}$, and $\mathrm{Co}$}

Arsenic concentration ranges from 0.01 (all species) to $2.3 \mathrm{mg} \mathrm{Kg}^{-1}$ (Cattle Egret) and from average levels of 0.27 in Grey Heron to $0.6 \mathrm{mg} \mathrm{Kg}^{-1}$ in Little Egret, values that are comparable with those reported in the literature and far below the average concentration of $10 \mathrm{mg} \mathrm{Kg}^{-1}$ measured in feathers from contaminated sites [39]. The effects of As on ecosystems are poorly known, especially in birds. As reported by Sanchez-Virosta et al. [40], its presence in body tissues has influenced reproductive success and wing growth; it has induced apoptosis and autophagy in mucous membrane cells of birds gizzard [41], and it has behaved as an endocrine disruptor causing individuals death [42,43]. Birds that feed on arthropod and aquatic macroinvertebrates may accumulate As and levels of As in bird feathers reflect its presence in the background or preys at the upper trophic level, as suggested by Lucia et al. [44] and Ali and Khan [45]. Data reported in the present work were close to those observed in heron populations where no detrimental effects were observed [46]. Consequently, we may assume that As concentration, up to $2.3 \mathrm{mg} \mathrm{Kg}^{-1}$, should not harm the investigated population.

The environmental effects of $\mathrm{Cr}$ are well known [47]. Some of its chemical forms, primarily hexavalent chromium, are toxic. Cr levels higher than $2 \mathrm{mg} \mathrm{Kg}^{-1}$ in bird feathers can affect embryo development, hatching success, kidney damage [48], reduction of bone growth rate [19], and chick viability [49]. In the present study, the $\mathrm{Cr}$ average values were 0.48 in Little Egret, 0.40 in Cattle Egret, and $0.59 \mathrm{mg} \mathrm{Kg}^{-1}$ in Grey Heron, and they were close to those reported by Rubio et al. [36]. On the contrary, they were one order of magnitude lower than tissue concentrations measured by Eisler [47]. The $\mathrm{Cr}$ levels detected in the present study do not pose a severe threat to local bird populations.

Lead is a toxic metal to wildlife, especially in gamebirds such as Anatidae and Galliformes [50]. The use of lead shot in hunting can cause toxic or sublethal effects, altering hematocrit level, impairing breeding activity, and reducing clutch sizes as observed in seagulls [51], in Great tit Parus major [52], and [53] Common eider Somateria mollissima. $\mathrm{Pb}$ concentrations of $4 \mathrm{mg} \mathrm{Kg}^{-1}$ in feathers are known to be potentially toxic [16], and levels exceeding a threshold concentration have been related to lower eggshell thickness and impaired eggshell structure [54], decreased survival of nestlings, altered 
recognition of siblings, and thermoregulation imbalance [48]; even lower $\mathrm{Pb}$ concentrations can induce severe histopathological damages and necrosis associated with reduced enzymatic functionality [55].

In the present study, $\mathrm{Pb}$ levels range from 0.15 to $1.67 \mathrm{mg} \mathrm{Kg}^{-1}$ in Little Egret and Cattle Egret and the average concentrations vary from 0.53 and $0.67 \mathrm{mg} \mathrm{Kg}^{-1}$ in Little Egret and Grey Heron, respectively; all measured values are about one order of magnitude lower than the threshold limit.

Nickel roles in bird metabolism are complex, and birds probably adopt eggshells as excretion pathways more than feathers [56]. Ni concentrations in avian tissues have rarely exceeded $2.0 \mathrm{mg} \mathrm{Kg}^{-1}$ and only occasionally reached $5 \mathrm{mg} \mathrm{Kg}^{-1}$; higher values have been detected in herring gulls $\left(9.9 \mathrm{mg} \mathrm{Kg}^{-1}\right)$ and mallard (12.5 $\left.\mathrm{mg} \mathrm{Kg}^{-1}\right)$ from heavily polluted areas [37]. It has been demonstrated that some species, such as duck chicks and adult, fed daily with high $\mathrm{Ni}$ concentration (up to $800 \mathrm{mg} \mathrm{Kg}^{-1}$ ) showed no or slight adverse effects, although high Ni levels $\left(68 \mathrm{mg} \mathrm{Kg}^{-1}\right.$ ) were detected in feathers after regrowth [37]. In the present study, $\mathrm{Ni}$ values range from $0.11 \mathrm{mg} \mathrm{Kg}^{-1}$ in Little Egret to $2.80 \mathrm{mg} \mathrm{Kg}^{-1}$ in Grey Heron, and from an average concentration of 0.50 in Cattle Egret to $1.3 \mathrm{mg} \mathrm{Kg}^{-1}$ in Grey Heron. These data were comparable with another study carried out on Heron species where no evidence of single nickel-mediated detrimental factors was observed [36].

\section{3. $\mathrm{Hg}$ and $\mathrm{Se}$}

Natural and anthropogenic processes lead to the release of inorganic $\mathrm{Hg}$ ( $\mathrm{IHg}$ ) [57] that can be methylated in monomethylmercury $(\mathrm{MeHg}$ ) mainly by microbial activity $[58,59]$. $\mathrm{IHg}$ and $\mathrm{MeHg}$ have different fates in the aquatic environment, since both can be assimilated by biota, but only $\mathrm{MeHg}$ is bioaccumulated in the aquatic trophic network [58]. MeHg in sediment and water can be taken up by phytoplankton and transferred to secondary consumers, such as fishes, invertebrates, and, consequently, birds [60,61]. Eisler [57] and Burger and Gochfeld [48] proposed $5.0 \mathrm{mg} \mathrm{Kg}^{-1}$ as the critical concentration of $\mathrm{Hg}$ in bird feathers associated with adverse effects. On the contrary, Goutner et al. [62] found no visible effects on the growth of Squacco Heron Ardeola ralloides when $\mathrm{Hg}$ reached $6.5 \mathrm{mg} \mathrm{Kg}^{-1}$, while Connell et al. [63] suspected adverse effects in herons, even below the threshold level for $\mathrm{Hg}$.

Mercury can be excreted both in eggshells and feathers. Its storage in the latter, being one of the preferred ways of excretion, therefore, can indicate the effect of a physiological protective action of the organism against the metal [64].

The average $\mathrm{Hg}$ concentration found in the present study, is below the threshold level and ranges from $0.7 \mathrm{mg} \mathrm{Kg}^{-1}$ in Little Egret and Cattle Egret to 2.8 in Grey Heron; however some individuals show higher values (namely 2.3, 3.2, and $4.2 \mathrm{mg} \mathrm{Kg}^{-1}$ in Little Egret, Grey Heron, and Cattle Egret, respectively). Moreover, $\mathrm{Hg}$ levels are about two- to three-fold higher in adults than in chicks for all the species (Table 2). As reported above, differences in mercury concentration are attributable to diet. However, different bioaccumulation levels in adults can also be affected by other variables, such as age or molting that occurs far away from the reproductive site. In addition, $\mathrm{Hg}$ concentration in chick feathers reflects the presence of contaminated prey in foraging areas surrounding the colony, resulting in a good predictor of the local environmental pollution [65]. Differently, Wang [66] detected $\mathrm{Hg}$ values ten-fold higher in adult Grey Heron $\left(0.55 \pm 0.06 \mathrm{mg} \mathrm{Kg}^{-1}\right)$ than in chicks $\left(0.055 \pm 0.024 \mathrm{mg} \mathrm{Kg}^{-1}\right)$ from coastal China and lower than those we reported (Table 2), and confirmed that the biomagnification process was usually significantly reduced in chicks as compared with adults [21,67]. Consequently, the higher Hg levels detected in Grey Heron chicks examined in the present study suggested the need for further investigation, as already suggested by Burger and Gochfeld [16] and Connell et al. [63].

Selenium concentrations range from $1.18 \mathrm{mg} \mathrm{Kg}^{-1}$ in Cattle Egret to $1.45 \mathrm{mg} \mathrm{Kg}^{-1}$ in Grey Heron, with a maximum value of $2.15 \mathrm{mg} \mathrm{Kg}^{-1}$ in Little Egret and $1.98 \mathrm{mg} \mathrm{Kg}^{-1}$ in Grey Heron and Cattle Egret. Selenium (Se) is an essential element, however, it can cause behavioral abnormalities, reproductive deficits, and increased mortality at concentrations slightly higher than those needed [68,69]. High concentrations of Se in liver (19-130 $\mathrm{mg} \mathrm{Kg}^{-1}$, [4]) and feathers (3.8-26 mg Kg${ }^{-1}$, [70]) have increased embryos mortality. There is no threshold level, although Heinz [70] found related sublethal 
effects at $1.8 \mathrm{mg} \mathrm{Kg}^{-1}$ concentration. Nevertheless, Se in the diet offers protection against the harmful effects of $\mathrm{Hg}$, as observed in numerous studies [16] carried out also on juveniles [71]. Specifically, the metabolic action occurred when the $\mathrm{Se} / \mathrm{Hg}$ molar ratio was higher than a unit [72,73]. Interestingly, in the present investigation, the molar ratio $\mathrm{Se} / \mathrm{Hg}$ is higher than a unit in juveniles of the three species and significantly lower in adults (Mann-Whitney $\mathrm{U}$ test, Gray Heron: $\mathrm{z}=-2.66, \mathrm{n}=17, p=0.008$; Little Egret: $\mathrm{z}=-3.49, \mathrm{n}=23, p<0.0001$; Cattle Egret: $\mathrm{z}=-3.79, \mathrm{n}=25, p<0.0001$, see Figure 4).

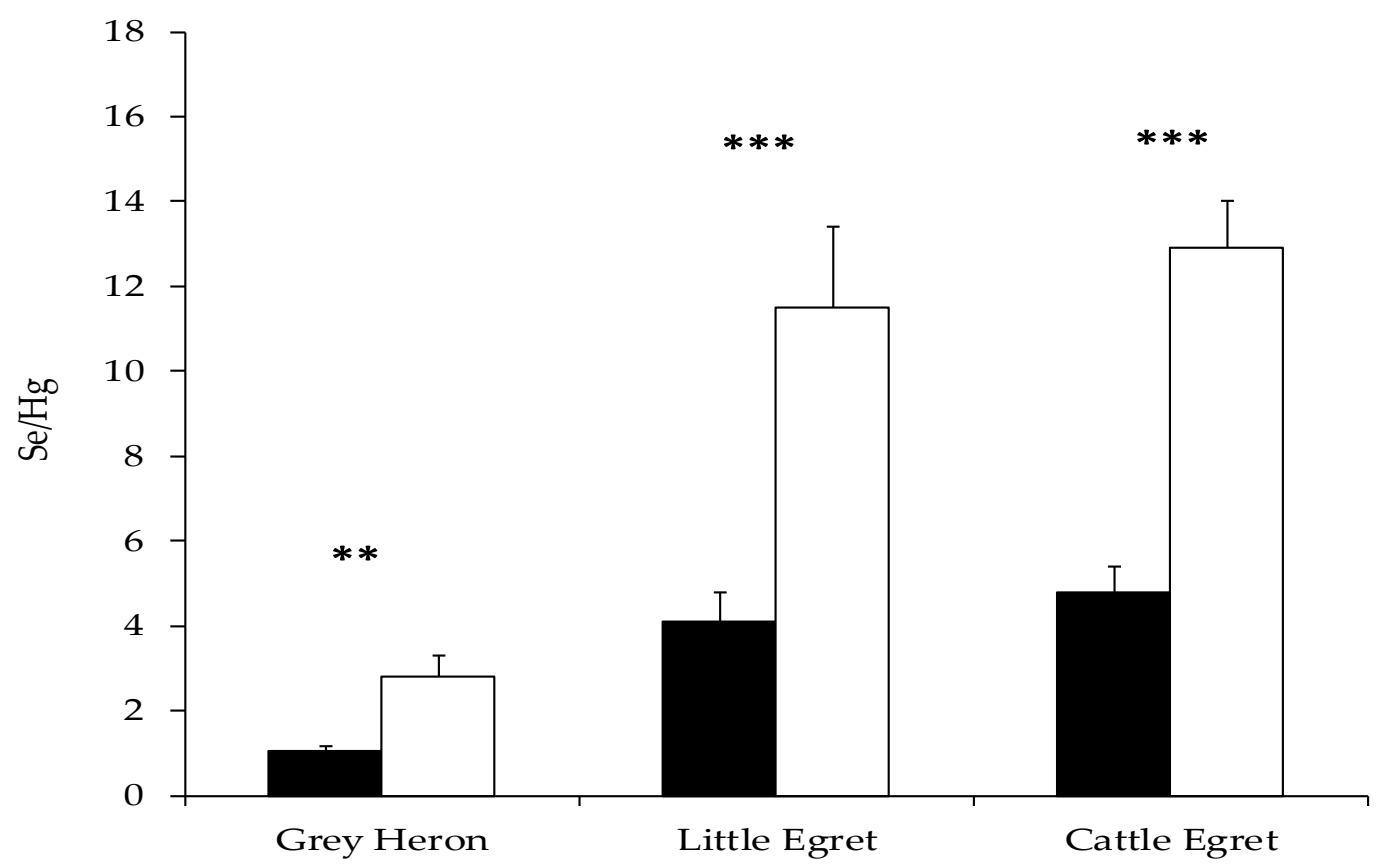

Figure 4. Se/Hg molar ratio and standard error in adults' (black) and chicks' (white) feathers. The asterisks mark a statistically significant difference at $\left.p<0.01{ }^{(* *}\right)$ and $p<0.001\left(^{* * *}\right)$ (Mann-Whitney U test).

\subsection{Trophic Level}

In waterbirds, the trophic level of predator and prey may be a crucial parameter in $\mathrm{Hg}$ bioaccumulation and biomagnification [74]. As observed in two fish-eaters, Grey Heron and Great Egret Egretta alba, the difference in $\mathrm{Hg}$ concentration seems to be due to the trophic level of prey [66]. Indeed, Grey Heron feeds mainly on Perccottus glehni and Misgurnus moloity, while the herbivorous Carassius auratus is the main food of Great Egret.

$\mathrm{Hg}$ concentrations (see Tables 1 and 2) differ significantly among the investigated species, and they are significantly higher in adults than in juveniles, suggesting that heron diet could account for such a difference. In the heronries of NW Italy, the Cattle Egret is a generalist feeder, well adapted to all agricultural habitat; its dietary spectrum ranges from small fishes to arthropods, insects, and amphibians. On the contrary, medium-size fishes, reptiles, and small mammals are everyday items in the Grey Heron diet, while that of Little Egret relies on small fish, frogs, aquatic crustaceans, and tadpoles.

Since the late 1990s, the Little Egret diet has changed for several reasons, such as a general reduction of the watershed, different water use in agriculture, and, probably, climate changes. As a result, diet bulk has shifted from fish and amphibians to terrestrial or mud species preys, such as worms, Louisiana crayfish Procambarus clarkii, terrestrial arthropods, and Gryllotalpa sp. [75]. As previously stated by Alvarez et al. [76] and also the results of the present study, bird species with terrestrial feeding habits show $\mathrm{Hg}$ contaminations lower than waterbirds. The relevance of fish, which is the primary source of $\mathrm{Hg}$ in the diet of the three investigated species, is highlighted by the results shown in Figure 1. In particular, the closeness of Little Egret centroid to Cattle Egret indicates that the two 
species share similar feeding habitats, confirming the shift of the Little Egret diet towards a diet based on insect and arthropods.

\section{Conclusions}

The results obtained in the present study confirm that most of the concentrations of the analyzed elements reflect the background concentration, and they are below the threshold levels, i.e., below concentration levels recognized as harmful for life, reproduction, and survival. On the contrary, $\mathrm{Hg}$ levels in some cases are close to the critical value, indicating that a potentially detrimental effect on individuals cannot be excluded and require in-depth investigation. Differently from adults, $\mathrm{Hg}$ levels in chicks are always lower and exclusively relate to the presence of contaminated prey in foraging areas surrounding the colony; $\mathrm{Hg}$ pattern in the three heron species confirms the dietary shift of the Little Egret during the last decade. Finally, the $\mathrm{Se} / \mathrm{Hg}$ ratio is higher in chicks than in adults, and as reported in the literature, higher levels of Se may protect chicks against the adverse effects of $\mathrm{Hg}$. Harmful and acute effects on the local heron population are unlikely; the conservation status of populations in northern Italy is probably more affected by other factors, such as climate change, altered aquatic environment, and, consequently, food quality.

Author Contributions: Corresponding author, L.C.; Conceptualization, L.C., M.S., F.M., and A.P.; resources, A.P. and L.C., investigation and analysis, F.M. and M.S., writing-original draft preparation, M.S. and L.C.; writing and editing, F.M. and A.P. All authors have read and agreed to the published version of the manuscript.

Funding: This research received no external funding.

Acknowledgments: The authors thank the Nature Reserve "Monticchie" (Somaglia-LO) for the assistance during field sampling and technical support.

Conflicts of Interest: The authors declare no conflict of interest.

\section{Appendix A}

Table A1. Detection and quantification limits of trace elements.

\begin{tabular}{ccccc}
\hline & IDL & IQL & MDL & MQL \\
\hline & $\left(\mu \mathrm{g} \mathrm{L}^{-1}\right)$ & $\left(\mu \mathrm{g} \mathrm{L}^{-1}\right)$ & $\left(\mathrm{mg} \mathrm{Kg}^{-1}\right)$ & $\left(\mathrm{mg} \mathrm{Kg}^{-1}\right)$ \\
$\mathbf{A s}$ & 0.06 & 0.2 & 0.03 & 0.1 \\
$\mathbf{C d}$ & 0.03 & 0.1 & 0.02 & 0.05 \\
$\mathbf{C o}$ & 0.01 & 0.03 & 0.01 & 0.02 \\
$\mathbf{C r}$ & 0.05 & 0.15 & 0.03 & 0.1 \\
$\mathbf{C u}$ & 0.01 & 0.03 & 0.01 & 0.02 \\
$\mathbf{F e}$ & 0.6 & 1.8 & 0.3 & 0.9 \\
$\mathbf{H g}$ & 0.06 & 0.2 & 0.03 & 0.1 \\
$\mathbf{M n}$ & 0.01 & 0.03 & 0.01 & 0.02 \\
$\mathbf{N i}$ & 0.01 & 0.03 & 0.01 & 0.02 \\
$\mathbf{P b}$ & 0.01 & 0.03 & 0.01 & 0.02 \\
$\mathbf{S e}$ & 0.2 & 0.6 & 0.1 & 0.3 \\
$\mathbf{Z n}$ & 0.05 & 0.15 & 0.03 & 0.1 \\
\hline
\end{tabular}

\section{References}

1. Bobbink, R.; Beltman, B.; Verhoeven, J.T.A.; Whigham, D.F. Wetlands: Functioning, Biodiversity Conservation, and Restoration; Ecological Studies (Analysis and Synthesis); Springer: Berlin/Heidelberg, Germany, 2006; ISBN 978-3-540-33189-6.

2. Aalto, E.; Capoccioni, F.; Mas, J.T.; Schiavina, M.; Leone, C.; De Leo, G.; Ciccotti, E. Quantifying 60 years of declining European eel (Anguilla anguilla L., 1758) fishery yields in Mediterranean coastal lagoons. ICES J. Mar. Sci. 2015, 73, 101-110. [CrossRef] 
3. Pit, I.R.; Van Egmond, E.M.; Dekker, S.C.; Griffioen, J.; Wassen, M.J.; Van Wezel, A.P. Ecotoxicological risk of trace element mobility in coastal semiartificial depositional areas near the mouth of the river Rhine, the Netherlands. Environ. Toxicol. Chem. 2018, 37, 2933-2946. [CrossRef] [PubMed]

4. Burger, J.; Gochfeld, M. Biomonitoring of heavy metals in the pacific basin using avian feathers. Environ. Toxicol. Chem. 1995, 14, 1233-1239. [CrossRef]

5. Vijver, M.G.; Peijnenburg, W.J. Metals and Metalloids in Terrestrial Systems: Bioaccumulation, Biomagnification and Subsequent Adverse Effects. Ecol. Impacts Toxic Chem. 2011, 43-62. [CrossRef]

6. Martinková, B.; Janiga, M.; Pogányova, A. Mercury contamination of the snow voles (Chionomys nivalis) in the West Carpathians. Environ. Sci. Pollut. Res. 2019, 26, 35988-35995. [CrossRef]

7. Marshall, D.J.; Abdelhady, A.A.; Wah, D.T.T.; Mustapha, N.; GödekeS, H.; De Silva, L.C.; Hall-Spencer, J.M. Biomonitoring acidification using marine gastropods. Sci. Total Environ. 2019, 692, 833-843. [CrossRef]

8. Burger, J.; Gochfeld, M. Marine Birds as Sentinels of Environmental Pollution. EcoHealth 2004, 1, $263-274$. [CrossRef]

9. Costantini, D.; Bustamante, P.; Brault-Favrou, M.; Dell'Omo, G. Patterns of mercury exposure and relationships with isotopes and markers of oxidative status in chicks of a Mediterranean seabird. Environ. Pollut. 2020, 260, 114095. [CrossRef]

10. Jackson, A.K.; Evers, D.C.; Eagles-Smith, C.A.; Ackerman, J.T.; Willacker, J.J.; Elliott, J.E.; Lepak, J.M.; Pol, S.S.V.; Bryan, C.E. Mercury risk to avian piscivores across western United States and Canada. Sci. Total Environ. 2016, 568, 685-696. [CrossRef]

11. Shore, R.F.; Taggart, M.A. Population-level impacts of chemical contaminants on apex avian species. Curr. Opin. Environ. Sci. Health 2019, 11, 65-70. [CrossRef]

12. Stauffer, J.; Panda, B.; Eeva, T.; Rainio, M.J.; Ilmonen, P. Telomere damage and redox status alterations in free-living passerines exposed to metals. Sci. Total Environ. 2017, 575, 841-848. [CrossRef] [PubMed]

13. Kanwal, S.; Abbasi, N.A.; Chaudhry, M.J.I.; Ahmad, S.R.; Malik, R.N. Oxidative stress risk assessment through heavy metal and arsenic exposure in terrestrial and aquatic bird species of Pakistan. Environ. Sci. Pollut. Res. 2020, 27, 12293-12307. [CrossRef]

14. Grunst, A.S.; Grunst, M.L.; Thys, B.; Raap, T.; Daem, N.; Pinxten, R.; Eens, M. Variation in personality traits across a metal pollution gradient in a free-living songbird. Sci. Total Environ. 2018, 630, 668-678. [CrossRef]

15. Janiga, M.; Haas, M. Alpine accentors as monitors of atmospheric long-range lead and mercury pollution in alpine environments. Environ. Sci. Pollut. Res. 2018, 26, 2445-2454. [CrossRef] [PubMed]

16. Burger, J.; Gochfeld, M. Mercury and Other Metals in Feathers of Common Eider (Somateria mollissima) and Tufted Puffin (Fratercula cirrhata) from the Aleutian Chain of Alaska. Arch. Environ. Contam. Toxicol. 2008, 56, 596-606. [CrossRef] [PubMed]

17. Ackerman, J.T.; Eagles-Smith, C.A.; Herzog, M.P.; Hartman, C.A.; Peterson, S.H.; Evers, D.C.; Jackson, A.K.; Elliott, J.E.; Pol, S.S.V.; Bryan, C.E. Avian mercury exposure and toxicological risk across western North America: A synthesis. Sci. Total Environ. 2016, 568, 749-769. [CrossRef] [PubMed]

18. Gerstle, C.T.; Drenner, R.W.; Chumchal, M.M. Spatial patterns of mercury contamination and associated risk to piscivorous wading birds of the south central United States. Environ. Toxicol. Chem. 2018, 38, 160-166. [CrossRef] [PubMed]

19. Kim, J.; Oh, J.-M. Lead and cadmium contaminations in feathers of heron and egret chicks. Environ. Monit. Assess. 2014, 186, 2321-2327. [CrossRef] [PubMed]

20. Soliman, K.M.; Mohallal, E.M.E.; Alqahtani, A.R.M. Little egret (Egretta garzetta) as a bioindicator of heavy metal contamination from three different localities in Egypt. Environ. Sci. Pollut. Res. 2020, 27, 23015-23025. [CrossRef]

21. Boncompagni, E.; Muhammad, A.; Jabeen, R.; Orvini, E.; Gandini, C.; Sanpera, C.; Ruiz, X.; Fasola, M. Egrets as Monitors of Trace-Metal Contamination in Wetlands of Pakistan. Arch. Environ. Contam. Toxicol. 2003, 45, 399-406. [CrossRef]

22. Deng, H.; Zhang, Z.; Chang, C.; Wang, Y. Trace metal concentration in Great Tit (Parus major) and Greenfinch (Carduelis sinica) at the Western Mountains of Beijing, China. Environ. Pollut. 2007, 148, 620-626. [CrossRef] [PubMed]

23. Kim, J.; Koo, T.-H. Heavy metal concentrations in diet and livers of Black-crowned Night Heron Nycticorax nycticorax and Grey Heron Ardea cinerea chicks from Pyeongtaek, Korea. Ecotoxicology 2007, 16, 411-416. [CrossRef] [PubMed] 
24. Hashmi, M.Z.; Malik, R.N.; Shahbaz, M. Heavy metals in eggshells of cattle egret (Bubulcus ibis) and little egret (Egretta garzetta) from the Punjab province, Pakistan. Ecotoxicol. Environ. Saf. 2013, 89, 158-165. [CrossRef] [PubMed]

25. Feathers of Bulbulcus ibis (L.) as a non-destructive biomonitoring tool for assessment of lead pollution: A case study from various severely contaminated wetland habitats. Biointerface Res. Appl. Chem. 2020, 10, 5085-5090. [CrossRef]

26. Ullah, K.; Hashmi, M.Z.; Malik, R.N. Heavy-Metal Levels in Feathers of Cattle Egret and Their Surrounding Environment: A Case of the Punjab Province, Pakistan. Arch. Environ. Contam. Toxicol. 2013, 66, 139-153. [CrossRef]

27. Balestrazzi, A. Piano Strutturale Comunale di Piacenza. Suolo e Sottosuolo; Internal Report 2007; Comune di Piacenza: Piacenza, Italy, 2007.

28. Arpa Lombardia. Agenzia Regionale per la Protezione Dell'ambiente 2020. Available online: https: //www.arpalombardia.it/Pages/ARPA_Home_Page.aspx (accessed on 16 April 2020).

29. Eeva, T.; Belskii, E.; Kuranov, B. Environmental pollution affects genetic diversity in wild bird populations. Mutat. Res. Toxicol. Environ. Mutagen. 2006, 608, 8-15. [CrossRef]

30. Mishra, V.K.; Singh, G.; Shukla, R. Impact of Xenobiotics Under a Changing Climate Scenario. In Climate Change and Agricultural Ecosystems; Elsevier: Amsterdam, The Netherlands, 2019; pp. 133-151.

31. Li, F.; Ding, C. Effects of heavy metal pollution on birds. Acta Ecol. Sin. 2007, 27, 296-302.

32. Mayer, J.; Donnelly, T.M. Heavy Metal Toxicity. In Clinical Veterinary Advisor; Elsevier: Amsterdam, The Netherlands, 2013; pp. 192-194.

33. Fasola, M.; Albanese, G.; Boano, G.; Boncompagni, E.; Bressan, U.; Brunelli, M.; Ciaccio, A.; Floris, G.; Grussu, M.; Guglielmi, R.; et al. Le garzaie in Italia, 2002. Avocetta 2007, 31, 5-46.

34. Pettine, M.; Bianchi, M.; Martinotti, W.; Muntau, H.; Renoldi, M.; Tartari, G. Contribution of the Lambro River to the total pollutant transport in the Po watershed (Italy). Sci. Total Environ. 1996, 192, 275-297. [CrossRef]

35. Solgi, E.; Mirzaei-Rajeouni, E.; Zamani, A. Feathers of Three Waterfowl Bird Species from Northern Iran for Heavy Metals Biomonitoring. Bull. Environ. Contam. Toxicol. 2020, 104, 727-732. [CrossRef]

36. Rubio, I.; Martínez-Madrid, M.; Fernández-Marín, B.; Galarza, A.; Rodriguez, P. Heavy metal concentration in feathers of Little Egret (Egretta garzetta) nestlings in three coastal breeding colonies in Spain. Ecotoxicology 2015, 25, 30-40. [CrossRef]

37. Eisler, R. Compendium of Trace Metals and Marine Biota; Elsevier: Amsterdam, The Netherlands, 2010; Volume I.

38. Kim, J.; Oh, J.-M. Biological monitoring of heavy metal contaminations using owls. J. Environ. Monit. 2012, 14, 1091-1097. [CrossRef]

39. Sánchez-Virosta, P.; Espín, S.; García-Fernández, A.J.; Eeva, T. A review on exposure and effects of arsenic in passerine birds. Sci. Total Environ. 2015, 569, 506-525. [CrossRef]

40. Sánchez-Virosta, P.; Espín, S.; Ruiz, S.; Salminen, J.-P.; García-Fernández, A.J.; Eeva, T. Experimental manipulation of dietary arsenic levels in great tit nestlings: Accumulation pattern and effects on growth, survival and plasma biochemistry. Environ. Pollut. 2018, 233, 764-773. [CrossRef] [PubMed]

41. Fei, D.; Zhao, H.; Wang, Y.; Liu, J.; Mu, M.; Guo, M.; Yang, X.; Xing, M.-W. The disturbance of autophagy and apoptosis in the gizzard caused by copper and/or arsenic are related to mitochondrial kinetics. Chemosphere 2019, 231, 1-9. [CrossRef] [PubMed]

42. Eisler, R.A. A Review of Arsenic Hazards to Plants and Animals with Emphasis on Fishery and Wildlife Resources. In Arsenic in the Environment, Part II: Human Health and Ecosystem Effects; Nriagu, J.O., Ed.; Wiley: New York, NY, USA, 1994; pp. 185-259, ISBN 978-0-471-30436-4.

43. Kunito, T.; Kubota, R.; Fujihara, J.; Agusa, T.; Tanabe, S. Arsenic in marine mammals, seabirds, and sea turtles. Rev. Environ. Contam. Toxicol. 2008, 195, 31-69. [CrossRef] [PubMed]

44. Lucia, M.; Bocher, P.; Cosson, R.P.; Churlaud, C.; Bustamante, P. Evidence of species-specific detoxification processes for trace elements in shorebirds. Ecotoxicology 2012, 21, 2349-2362. [CrossRef]

45. Ali, H.; Khan, E. Trophic transfer, bioaccumulation, and biomagnification of non-essential hazardous heavy metals and metalloids in food chains/webs-Concepts and implications for wildlife and human health. Hum. Ecol. Risk Assess. Int. J. 2018, 25, 1353-1376. [CrossRef]

46. Padula, A.M.; Tager, I.B.; Carmichael, S.L.; Hammond, S.K.; Yang, W.; Lurmann, F.W.; Shaw, G.M. Traffic-related air pollution and selected birth defects in the San Joaquin Valley of California. Birth Defects Res. Part A Clin. Mol. Teratol. 2013, 97, 730-735. [CrossRef] 
47. Eisler, R. Chromium Hazards to Fish, Wildlife, and Invertebrates: A Synoptic Review; Contaminant Hazard Reviews Report 6. Biological Report 85 (1.6); US Fish and Wildlife Service: Laurel, MD, USA, 1986.

48. Burger, J. Effects of Lead on Birds (Laridae): A Review of Laboratory and Field Studies. J. Toxicol. Environ. Health Part B 2000, 3, 59-78. [CrossRef]

49. Shahbaz, M.; Hashmi, M.Z.; Malik, R.N.; Yasmin, A. Relationship between heavy metals concentrations in egret species, their environment and food chain differences from two Headworks of Pakistan. Chemosphere 2013, 93, 274-282. [CrossRef]

50. Pain, D.J.; Mateo, R.; Green, R.E. Effects of lead from ammunition on birds and other wildlife: A review and update. Ambio 2019, 48, 935-953. [CrossRef] [PubMed]

51. Vallverdú-Coll, N.; Mateo, R.; Mougeot, F.; Ortiz-Santaliestra, M.E. Immunotoxic effects of lead on birds. Sci. Total Environ. 2019, 689, 505-515. [CrossRef] [PubMed]

52. Markowski, M.; Kaliński, A.; Bańbura, M.; Glądalski, M.; Wawrzyniak, J.; Skwarska, J.; Bańbura, J. Effects of experimental lead exposure on physiological indices of nestling great tits Parus major: Haematocrit and heterophile-to-lymphocyte ratio. Conserv. Physiol. 2019, 7, coz067. [CrossRef] [PubMed]

53. Morrill, A.; Provencher, J.F.; Gilchrist, H.G.; Mallory, M.L.; Forbes, M.R. Anti-parasite treatment results in decreased estimated survival with increasing lead $(\mathrm{Pb})$ levels in the common eider Somateria mollissima. Proc. R. Soc. B Biol. Sci. 2019, 286, 20191356. [CrossRef] [PubMed]

54. Eeva, T.; Lehikoinen, E. Egg shell quality, clutch size and hatching success of the great tit (Parus major) and the pied flycatcher (Ficedula hypoleuca) in an air pollution gradient. Oecologia 1995, 102, 312-323. [CrossRef]

55. Kou, H.; Ya, J.; Gao, X.; Zhao, H.-F. The effects of chronic lead exposure on the liver of female Japanese quail (Coturnix japonica): Histopathological damages, oxidative stress and AMP-activated protein kinase based lipid metabolism disorder. Ecotoxicol. Environ. Saf. 2020, 190, 110055. [CrossRef]

56. Fu, J.; Wang, Q.; Wang, H.; Yu, H.; Zhang, X. Monitoring of non-destructive sampling strategies to assess the exposure of avian species in Jiangsu Province, China to heavy metals. Environ. Sci. Pollut. Res. 2013, 21, 2898-2906. [CrossRef]

57. Eisler, R. Mercury Hazards to Fish, Wildlife, and Invertebrates: A Synoptic Review; Contaminant Hazard Reviews Report 1987, 10; US Fish and Wildlife Service: Laurel, MD, USA, 1987.

58. Gorokhova, E.; Soerensen, A.L.; Motwani, N.H. Mercury-methylating bacteria are associated with copepods: A proof-of-principle survey in the Baltic Sea. PLoS ONE 2020, 15, e0230310. [CrossRef]

59. Siedlikowski, M.; Bradley, M.; Kubow, S.; Goodrich, J.M.; Franzblau, A.; Basu, N. Bioaccessibility and bioavailability of methylmercury from seafood commonly consumed in North America: In vitro and epidemiological studies. Environ. Res. 2016, 149, 266-273. [CrossRef]

60. Rimmer, C.C.; Miller, E.K.; McFarland, K.P.; Taylor, R.J.; Faccio, S.D. Mercury bioaccumulation and trophic transfer in the terrestrial food web of a montane forest. Ecotoxicology 2009, 19, 697-709. [CrossRef]

61. Driscoll, C.T.; Han, Y.-J.; Chen, C.Y.; Evers, D.C.; Lambert, K.; Holsen, T.M.; Kamman, N.C.; Munson, R.K. Mercury Contamination in Forest and Freshwater Ecosystems in the Northeastern United States. Bioscience 2007, 57, 17-28. [CrossRef]

62. Goutner, V.; Furness, R.W.; Papakostas, G. Mercury in feathers of Squacco Heron (Ardeola ralloides) chicks in relation to age, hatching order, growth, and sampling dates. Environ. Pollut. 2001, 111, 107-115. [CrossRef]

63. Connell, D.; Wong, B.; Lam, P.K.; Poon, K.; Lam, M.; Wu, R.; Richardson, B.; Yen, Y. Risk to breeding success of Ardeids by contaminants in Hong Kong: Evidence from trace metals in feathers. Ecotoxicology 2002, 11, 49-59. [CrossRef]

64. Sepúlveda, M.S.; Frederick, P.C.; Spalding, M.G.; Williams, G.E. Mercury contamination in free-ranging great egret nestlings (Ardea albus) from Southern Florida, USA. Environ. Toxicol. Chem. 1999, 18, 985-992. [CrossRef]

65. Abdennadher, A.; Ramírez, F.; Romdhane, M.S.; Ruiz, X.; De Jover, L.; Sanpera, C. Little Egret (Egretta garzetta) as a bioindicator of trace element pollution in Tunisian aquatic ecosystems. Environ. Monit. Assess. 2010, 175, 677-684. [CrossRef] [PubMed]

66. Wang, Q.; Zhang, Z.; Zhou, X.; Lu, X. Mercury distribution and accumulation in typical wetland ecosystems of Sanjiang Plain, Northeast China. Chin. Geogr. Sci. 2013, 23, 49-58. [CrossRef]

67. Sanpera, C.; Moreno, R.; Ruiz, X.; De Jover, L. Audouin's gull chicks as bioindicators of mercury pollution at different breeding locations in the western Mediterranean. Mar. Pollut. Bull. 2007, 54, 691-696. [CrossRef] [PubMed] 
68. Eisler, R. Selenium Hazards to Fish, Wildlife, and Invertebrates: A Synoptic Review; Contaminant Hazard Reviews Report 1985, 5; US Fish and Wildlife Service: Laurel, MD, USA, 1985.

69. Ohlendorf, H.M.; Heinz, G.H. Selenium in Birds. In Environmental Contaminants in Biota; Informa UK Limited: London, UK, 2011; pp. 669-702.

70. Patnode, K.A.; Schrank, C.S.; Beyer, W.N.; Heinz, G.H.; Redmon-Norwood, A.W. Environmental Contaminants in Wildlife: Interpreting Tissue Concentrations. J. Wildl. Manag. 1997, 61, 1449. [CrossRef]

71. Ndu, U.; Lamb, J.S.; Janssen, S.; Rossi, R.; Satgé, Y.; Jodice, P. Mercury, cadmium, copper, arsenic, and selenium measurements in the feathers of adult eastern brown pelicans (Pelecanus occidentalis carolinensis) and chicks in multiple breeding grounds in the northern Gulf of Mexico. Environ. Monit. Assess. 2020, 192, 286-289. [CrossRef]

72. Peterson, S.A.; Ralston, N.V.; Peck, D.V.; Van Sickle, J.; Robertson, J.D.; Spate, V.L.; Morris, J.S. How Might Selenium Moderate the Toxic Effects of Mercury in Stream Fish of the Western U.S.? Environ. Sci. Technol. 2009, 43, 3919-3925. [CrossRef] [PubMed]

73. Qiu, G.; Abeysinghe, K.S.; Yang, X.-D.; Xu, Z.; Xu, X.; Luo, K.; Goodale, E. Effects of Selenium on Mercury Bioaccumulation in a Terrestrial food Chain from an Abandoned Mercury Mining Region. Bull. Environ. Contam. Toxicol. 2019, 102, 329-334. [CrossRef]

74. Duvall, S.E.; Barron, M.G. A Screening Level Probabilistic Risk Assessment of Mercury in Florida Everglades Food Webs. Ecotoxicol. Environ. Saf. 2000, 47, 298-305. [CrossRef] [PubMed]

75. Fasola, M.; Cardarelli, E. Long-term changes in the food resources of a guild of breeding Ardeinae (Aves) in Italy. Ital. J. Zoöl. 2014, 82, 1-13. [CrossRef]

76. Alvárez, C.R.; Jiménez-Moreno, M.; Alonso, L.L.; Gómara, B.; Bernardo, F.J.G.; Martín-Doimeadios, R.C.R.; González, M. Mercury, methylmercury, and selenium in blood of bird species from Doñana National Park (Southwestern Spain) after a mining accident. Environ. Sci. Pollut. Res. 2013, 20, 5361-5372. [CrossRef] [PubMed]

Publisher's Note: MDPI stays neutral with regard to jurisdictional claims in published maps and institutional affiliations.

(C) 2020 by the authors. Licensee MDPI, Basel, Switzerland. This article is an open access article distributed under the terms and conditions of the Creative Commons Attribution (CC BY) license (http://creativecommons.org/licenses/by/4.0/). 